\title{
Macrothink

\section{Reading Interests and Habits of the Federal Polytechnic, OFFA, Students}

\author{
Abdulwahab Olanrewaju Issa, PhD. \\ Senior Lecturer \& Head, Department of Library and Information Science, \\ University of Ilorin, Ilorin, Kwara State, \\ E-mail: abdulwahab.issa@yahoo.com
}

\begin{abstract}
Mulikat Bola Aliyu
Principal Lecturer and Head, Department of Library and Information Science,

The Federal Polytechnic, Offa, Kwara State,

E-mail: mulikataliyu@yahoo.com
\end{abstract}

Rachel Bisilola Akangbe,

Director, Kwara State Library Board, Ilorin, Kwara State,

E-mail: akangbebisi@yahoo.com

Adegboyega Francis Adedeji

Principal Librarian, The Federal Polytechnic, Offa, Kwara State.

E-mail: adedeji.adegboyega@yahoo.com

Accepted: November 13, 2011 Published: March 3, 2012

Doi:10.5296/ijld.v2i1.1470ＵRL: http://dx.doi.org/10.5296/ijld.v2i1.1470

\begin{abstract}
This study investigates the reading interests and habits of Mass Communication and Library and Information Science students at the Federal Polytechnic, Offa, Kwara State. The survey research method was adopted. A pretest involving NDII and HND II Accountancy students at the same institution was conducted to establish the reliability co-efficient of the instrument Reading Interests and Habits Questionnaire (RIHQ) at $\mathrm{r}=0.88$. Of 250 copies of the questionnaire administered, 246 were used for the analysis. Some of the significant findings
\end{abstract}


are that utilitarian reading was more prevalent among the studied group; found to read mostly their personal textbooks and notebooks particularly during examination periods. Major source of their reading materials was their lecturers' textbooks and notebooks. Factors militating against their developing reading interests and habits include unconducive home environment, low socio-economic status of parents, non-availability of relevant reading materials and unserious attitude. To combat these, proper home upbringing, re-orientation in parenting and effective school library system operation were recommended.

\section{Introduction}

Learning which starts right from birth entails acquiring knowledge about various phenomena and understanding them. The more a person reads, the more he learns. Reading, which Orasamu (1982) defined as the art of interpreting printed and written words, is one of the most effective processes of conscious learning and sometimes, it influences the extent and accuracy of information as well as the attitudes, morals, beliefs, judgment and action of readers. A creative and pragmatic education involves the habit of personal investigation. The art of personal investigation requires self-study to be followed by self-thinking and analysis. Self-study, otherwise referred to as reading at one's own accord, requires a habit, which, according to Smith (1982), is known as reading habit. Reading makes way for a better understanding of one's own experiences and it can be an exciting voyage to self-discovery. "The reading habit is best formed at a young impressionable age in school, but once formed it can last one's life" (Green, 2001).

To know about the world and its environment, a child helps himself through reading books, newspapers and other magazines (Deavers, 2000). Once the child has been taught to read and develop a love for books, he can explore for himself the wealth of human experience and knowledge. Children, missing the opportunity of getting in touch with books at this stage, find it hard to acquire reading habit in their later years. According to Fisher (2001) "... reading is an intellectual action which is possible only if a man has formed a habit of reading and practicing it since childhood". The reading habit, therefore, plays a very crucial role in enabling a person to achieve practical efficiency. "Laws die but books never." Indeed, books are the most suitable medium through which knowledge is transmitted from generation to generation. Gallo (2007) enthused, "books, yield their best to you, if you read them at the age at which each particular masterpiece can ideally be chewed and digested".

There is little knowledge about the everyday reading practices of tertiary education students and how these practices affect their academic achievement. Everyday reading consists of individuals' reading activities for a variety of purposes, such as for relaxation or information Previous research has documented that, from middle childhood through adulthood, reading becomes a major component of studying, and much information learned through studying is initially acquired through reading. The everyday reading activities in which students engage may, therefore, considerably influence their studying skills and subsequent academic performance. There is a general sense in which one appreciates the link between good habits of reading and the academic performance of students generally. Nigeria, like other African countries, adopts the English Language as its official language of communication or Lingua Franca. This has a great implication for the formation of good reading habits among Nigerians, 
especially, the youths who have to study and learn in a second language and outside of their mother tongue. To form the good habits of reading, therefore requires constant and continual practice on the part of the learner.

The term "habit" has been defined as "something that you do often or regularly" (Grellet, 1987). On its own part, "reading" is the act of getting meaning from printed or written words, which is the basis for learning and one of the most important skills in everyday life (Guthrie, Benneth \& McGough, 2007). This explains why reading is usually associated with books as only the written words provide a complete picture of the act of reading. There is no doubt that through reading, the individual is able to build or fix things, enjoy stories, discover what others believe and develop ideas/beliefs of their own. Thus, reading provides the key to all forms of information necessary for our day-to-day survival and growth. Broadly, reading is linked closely with other uses of language and with thinking. Central to the concept of reading is its dependence on the readers' memory and experience in order to understand what is read. It also involves how well a reader remembers, uses and reacts to the materials read; stressing such skills as word recognition, vocabulary development and comprehension.

It follows then that if you are in the practice of reading regularly without thinking about it because of the permanence of its continuity, one can conclude that good reading habits have been formed. This is because a habit has been formed when an individual does something many times unconsciously having become a part and parcel of such a person's life. Hence, reading habits have been conceived as positive in that they have the potency to contribute meaningfully to the growth, development and progress of such individuals as engaged in the habits. Incidentally, many Nigerian students do not belong in the category of those with good reading habits. Their poor/bad reading habits could be partly held responsible for general poor performance that the school systems usually record in both internal and external examinations. This affects all aspects of their examinable subjects but most especially the English language examination, which also serves as the general medium of official communication and conduct of all examinations. Perhaps, due to lack of good reading habits among the students, academic performance with respect to their examination results had been dismal, nowadays creating a great source of worry and concern to all stakeholders in the educational sub-sector.

Even the cankerworm of examination malpractices may be traceable to the prevalent poor reading interests and habits among the wide spectrum of students. In addition, the by-products of scientific and technological inventions and innovations have also contributed greatly to the dwindling fortunes of the good practice of reading among majority of the students. Today, many of them prefer to watch cinemas and other shows on the television, audio- $C D$, video-CD and playing video-games to reading. The setting and atmosphere of "crashed programmes," quite prevalent in the school systems today have not been supportive to the development of the good practice of reading. Thus, the enthusiasm associated with the urge to engage in reading practices voluntarily, pleasurably and extensively are almost nearly absent among the greater number of students in the schooling systems today.

\section{The Problem Statement}

Regardless of the discipline or course of study by students of Federal Polytechnic, Offa, as it is elsewhere, English Language is the official medium of communication, with 
which all academic activities are transacted. A corollary can thus be established between the reading habits of students and their academic performance to the extent that a positive relationship is suggested.

However, observations reveal that many students read for examination purposes only; as they hardly read beyond their examinations or their course of study. This implies that such students do not enjoy reading voluntarily- a situation that can have a negative influence on their academic performance. Against this background therefore, this study investigates the influence of reading interests and habits among the HND II students of Mass Communication and Library and Information Science at the Federal Polytechnic, Offa, Kwara State, with a view to examining their reading patterns vis-a-vis their academic performance. Specific objectives are to: identify their reading interests and the kind of materials they read often; the reasons for their preferences for reading such materials; know how and where they obtain the materials and ascertain the influence of reading habits on their academic performance as well as identify the problems affecting the development of good reading habits among them.

\section{Study Justification}

The justification of this study is embedded in the many benefits expected from its findings. One, it will help create desired awareness among students of the Federal Polytechnics, Offa, on the need for developing good reading habits for a well-rounded academic engagement. Also, the institution's Library Authorities would be better positioned to provide for the reading interests of the students; especially by providing relevant materials, conducive environment and above all, library programmes to stimulate students' reading interests. In the end, stakeholders would be able to gain a better understanding of the need to develop good reading habits for academic accomplishment. This knowledge is crucial to better planning and administration of the educational sub-sector of the nation's economy, simply because the more one knows about students' reading interests and habits, the better equipped one becomes in improving the skills, recommending books, suggesting research projects, and holding reading conferences that would affect them positively.

\section{The Literature Review}

One of the many problems students face nowadays is not their inability to read but their lack of interest, indifference or rejection of reading. Studies based on reading habits have particularly focused on the importance of the promotion of specific strategies to: capitalize on their interests, make reading materials accessible, build a conducive environment, allow time to read in school, provide significant adult models and use motivational techniques (Clary, 1991). The prevention of coping strategies by students who lack literacy skills has been the focus of a research on the identification of teacher behaviours that correlate with student achievement, as well as on teachers' perceptions of and reactions to students' behaviours and on students' usage of these coping strategies (Brozo, 1990).

There is also the lack of autonomy by the students as readers in accomplishing the goals of their readings. As stated by Kletzien \& Bednar (1988), too often, students approach reading assignments with no idea of why they are studying or what they are supposed to learn relying on what they were told by the teachers. They observed that students are not used to 
taking control of their own reading and that they are lacking in meta cognition, knowledge, and control of the four variables: person, goal, task, and strategies (Baker \& Brown, 1984; Flavell, 1979). Metacognition is precisely the subject of a study conducted by Lindquist-Sandmann (1987), which consists of developing metacognitive strategies with high school students never forgetting the psycholinguistic implications of the whole process. These implications are specially connected with what Perin (1988) identified as the schema activation in literacy instruction and in the effectiveness of the comprehension process.

Similarly, many other studies have tried to identify and explain the process of the activation of background knowledge, all having the schema theoretic model of reading (Anderson \& Pearson, 1984) as a working basis. Also in the psycholinguistic scientific field, Gardner \& Smith (1987) have produced a body of research that suggests that some students may not enjoy reading because of a basic psychological problem: the lack of the ability to take the perspective of another person, which can affect their enjoyment of literature and their ability to understand what they have read.

This relationship between the reader and the text has also been studied by Sager (1989), who states that reading demands a quality of engagement beyond the application of skills and processing of text and that students need not only to decode the text but also to think through it and experience it, anticipating, questioning, appreciating, puzzling over, confirming, being curious about, imagining.

College reading comprehension programmes in some universities have also been the basis for the elaboration and publication of study guides specially directed to students. In McWhorter's reading and study guide (2001) the author emphasizes the importance of critical thinking approaches to reading and of study as an active learning process. The author presents the basic techniques for college success, including active reading and note taking, offering strategies for strengthening literal and critical comprehension, improving vocabulary skills and developing reading flexibility, using methods for reading and learning from textbook assignments and for taking exams.

Wong (2000), Pauk (2001) and Hopper (2001) developed guides for students where we can find exercises and explanations on particular techniques for taking useful notes, reading in an effective way and retaining a textbook assignment. The same goal had already led Marzano \& Paynter (1994) to publish a guide on the new approaches to literacy to help students to develop their reading and writing skills based on their work with teachers on the effectiveness at enhancing the key literacy skills and on the survey of this research. Shapiro (1996) developed another kind of study based on a wider approach to the subject that concerns the general academic skills problems of the students designed not only for students and instructors but also for psychologists and reading and curriculum specialists. It is also interesting to refer to more instructional compendiums on reading strategies and practices, specially for teachers, developed by Tierney \& Readence (2000) and Greenall \& Swan (1986), which have been used in graduate and undergraduate support programmes.

In fact, there are numerous studies about reading and study strategies of higher education students and many have focused, using different approaches and methodologies, precisely on many Reading/Comprehension specific strategies as the visualization of content in a text, main idea identification, vocabulary assimilation, key words detection, context 
usage, the use of mnemonics for memorization and highlighting, the use of dictionaries and grammars, and so forth. Some of these studies found that the most successful individuals understand and use a variety of active study strategies to control and monitor their learning (Garner 1987; Yaworski, 1998), applying particular strategies only when appropriate and that these students can also explain the strategies they use and can describe whether or not particular strategies prove to be useful in particular situations (Ruzic, 2001). The theoretical perspective of this study therefore is that students will become active, interested readers if they develop intrinsic motivations such as curiosity, aesthetic enjoyment, and challenge. Equally important to active reading is the development of the cognitive strategies associated with searching for information, comprehending literary works, and communicating to others in writing.

\section{The Challenges of Developing Good Reading Interests and Habits in Nigeria}

The problem of illiteracy is still pervasive in Nigeria, as it is in other Third world countries; one of the main factors militating against reading habit formation and sustenance in Nigeria. Okekwe (2006) reported the outcomes of The Lumina Foundation, some of which include certain indicators on the appalling level of literacy in the country: Literates 19\%; Semi-literates $14 \%$ and Illiterates $67 \%$. Some of the reasons for the persistent illiteracy rate; especially from the social and economic perspectives as revealed by the study include the followings:

1. Wealth is priority

2. Poverty level is high

3. Alternative ways of getting rich abound

4. Education is unfortunately devalued by the state and the society. For example, the Universities are not well funded, teachers are not well remunerated. Both teachers and students keep protesting the situation, which disrupts the academic system

5. Getting educated is made unattractive and is no longer a priority because of unemployment of graduates

6. Moral values are low.

7. Insensitivity to knowledge acquisition.

This probably explains why only a few people engage in reading while this few do not have healthy reading habits as depicted by the reading patterns of Nigerians with emphasis in the following areas: reading soft sells for vanity and gossip $22 \%$; reading newspapers for information $13 \%$; not reading due to low buying power $41 \%$; reading for utilitarian purpose $22 \%$ and reading for leisure $2 \%$. Thus, most Nigerians are associated with reading for utilitarian purpose, have aversion for sustained reading; lack the habit of reading for leisure and pleasure, live under hostile economic constraints of underdevelopment; contend with limited relaxation time and extended family pressure as well as wrong perception of books and their importance.

Studies in Reading Interests and Habits of Students

Cabral (2002) studied the main Reading/Comprehension strategies applied by higher education first-year students during their daily learning academic tasks and their major difficulties in this field. The research process consists in a measuring frequency Lickert scale 


\section{Ml Macrothink}

questionnaire completed by 1,000 students from four of the main Portuguese state universities from science and engineering courses. Reading/Comprehension level groups were formed according to the competence and abilities of the students. Results indicate that the majority of the students had an intermediate level of proficiency in this field even as they tend to use general strategies connected with their specific academic tasks and study habits. However, they tend to avoid the usage of strategies that involve interaction with teachers and more specific strategies that may control/determine their academic writing tasks and that imply a higher scope of proficiency.

Stachelek (2005) compared the reading interests and habits of American and Canadian senior high school students and examined the extent to which the English curricula in their schools coincide with those reading interests. Questionnaires were distributed to a total of 680 students in three schools (urban, suburban, and rural) in the New Britain, Connecticut, area and in three similar schools in the Edmonton, Alberta (Canada) area. English teachers and school librarians were also surveyed in regard to student reading interests and English curricula.

Results of the study are reported according to the following categories: the degree to which students indicate they like to read and the number of books read per month; the most-liked and least-liked book titles; the most popular book categories; students' preference for paperback, rather than hardbound, books; ways in which students learn about book titles; the interaction of reading books and viewing movies made from the books; the extent to which students read comic books, newspapers, and magazines; student opinions about the school library; and student opinions and suggestions regarding the English curriculum in their schools.

Higginbotham (2006) examine the reading interests of middle school- sixth, seventh, and eighth grade- students in a metropolitan, public middle school located in a southeastern state. It was hypothesized that the data would reveal statistically significant categories of reading interest, and would reveal significant differences between categorical interests by gender. The students clearly indicated a strong preference for the categories of Humor and Horror. The students also reported an interest in Mystery, Historical Fiction, Adventure, Science Fiction, and the non-fiction category of Animals. The results of this study showed differences in interest by gender, which are congruent with many of society's stereotypes. The females reported a stronger interest in Romance, Friendship, Animal Stories, Adventure, and Historical Fiction, while the males reported stronger preferences for the categories of Sports and Science. Also, the male respondents had a stronger preference for non-fiction than did the female respondents.

Stoefen-Fisher (1990) investigated the factors used by teachers of the hearing impaired in identifying the reading interests of their students and the accuracy of their judgments in comparison to students' responses on a reading interest inventory. Twenty teachers of the hearing impaired were asked to judge the top two reading interest areas for each of the 82 students and to describe the factors they used in making their judgments. The respondents completed a reading interest inventory. Their results were compared with their teachers' judgments. Results indicated that teachers were only moderately accurate in judging their students' reading interests. 
Smith (1992) examined the everyday reading activities and reading attitudes of gifted and non-gifted high school students. The results indicated several differences in reading activities between the two groups pertaining to types of materials read and amount of time-spent reading. Takase (2007) investigates factors motivating Japanese high school students to read English extensively, assessing 219 female high school students who participated in an extensive reading program for one academic year. The results showed that the two most influential factors were students' intrinsic motivation for first language (L1) reading and second language (L2) reading.

However, no positive relationship between $\mathrm{L} 1$ reading motivation and L2 reading motivation was observed. Follow-up interviews, conducted with one-third of the participants, illuminated aspects of the motivation that the quantitative data did not reveal. Several enthusiastic readers of Japanese were not motivated to read in English due to the gaps between their abilities to read in Japanese and in English. In contrast, the intrinsic motivation of enthusiastic readers of English was limited to L2 reading and did not extend to their L1 reading habits.

Panigrahi and Panda (2007) examined the reading interests and information eliciting sources of 130 school going children of two leading English-medium schools in Rourkela, India and identifies factors that hinder the development of reading interests and suggested measures required for improvement. Drawing from data obtained from a two-page student questionnaire mailed to a number of Connecticut English and reading teachers in all types of schools, Gallo (2006) reports on the reading interests and habits of students in grades four through twelve. Usable responses were received from 3,339 students from 51 schools in 37 different towns and cities. Findings are arranged in the following categories: (1) types of readers, (2) personal reading versus required reading, (3) favorite types of books, (4) favorite books, (5) most recent title read, (6) favorite authors, (7) repeated readings of authors, (8) assigned books, (9) hours of homework per week, (10) hours per week reading outside of school, (11) number of books read outside of class in an average month, (12) hours of television watched in an average week, (13) influence of television and movies on reading, (14) sources of information about good books to read, (15) sources of books, (16) paperbacks versus hardbacks, (17) book purchases, (18) book clubs, (19) places in school where paperbacks can be bought, (20) characteristics of books that appeal to students, (21) number of books owned, (22) what students would buy with an extra eight dollars, (23) records and books purchased during the previous semester, (24) how much students were willing to spend to buy a book, (25) percentages of students whose parents read the same book, (26) parental censorship, and (27) self-censorship.

\section{Research Methodology}

The survey research design was adopted in this study. The two departments comprised of 610 students across NDI, NDII, HNDI and HNDII, out of which 367 are in the HNDII classes, which constitute the study population. The choice of both Library and Information Science as well as Mass Communication departments was due to their close affinity, on the one hand and the importance of reading to them. The exclusion of NDI and HNDI was hinged on the fact that a good measure of the individual students' reading practice can hardly 
be ascertained at earlier stages, occasioned by the largely unstable circumstances in which students often find themselves during this period of settling down in school. Thus, Table 1 provides a breakdown of the compositions in each of the four arms of the two departments.

Table 1: Study Population

\begin{tabular}{|l|l|l|l|l|l|}
\hline Department & NDI & NDII & HNDI & HNDII & Total \\
\hline $\begin{array}{l}\text { Library and } \\
\text { Information }\end{array}$ & 66 & 118 & 32 & 50 & 266 \\
\hline $\begin{array}{c}\text { Mass } \\
\text { Communication }\end{array}$ & 82 & 118 & 63 & 81 & 344 \\
\hline Total & 148 & 236 & 95 & 131 & 610 \\
\hline
\end{tabular}

Source: Field study (2010)

\section{Study Sample and Sampling Procedure}

The proportional stratified random sampling technique was used to ensure an equitable representation of the sample group members while also reducing bias. This choice also ensures that each proportional stratum is as homogeneous as possible. Thus, from the study population of 367, a sample size of 250 was drawn. In both sets of student groups, about $90 \%$ of the population was drawn, as indicated in Table 3.4.

Table 2: Study Sample Size

\begin{tabular}{|c|l|l|l|}
\hline Department & NDII - & HNDII & Total \\
\hline Library and Information Science & 118 & 50 & 120 \\
\hline Mass Communication & 118 & 81 & 130 \\
\hline Total & 236 & 131 & 250 \\
\hline
\end{tabular}

\section{Source: Field study (2010)}

The Influence of Reading Habits Questionnaire (IRHQ), and participant observation served as instruments for data collection. To ensure that the questionnaire was reliable, a pre-test was conducted on students of Accountancy Department in the same Institution where 65 copies of the self-developed questionnaire were administered on some ND and HND categories. These students did not form a part of the study's sample. The split-half approach, adjusted by Spearman Brown Formulae was applied; by dividing the scale in each section into two halves, using the odd-numbered items for one and the even-numbered for the other. Each of the two sets of the items was treated as a separate scale for the questionnaire and then correlated with the two sub-scales taken as a measure of reliability. Using the Spearman Brown method at $\mathrm{r}=0.88$, the correlation co-efficient obtained between the two halves was $\mathrm{r}=0.92$. This indicated $\boldsymbol{I} \boldsymbol{R} \boldsymbol{H Q}$ was reliable. One of the researchers administered the instrument personally on the sampled group during the course of lectures in the both departments therefore taking the advantage of being a staff in the Institution and in one of the departments concerned. This allowed for the early completion of the data-gathering process and the high rate of completion/return of the instrument. The descriptive statistics, deploying frequency tables and simple percentage, was used for data analysis. 


\section{Data Analysis and Discussion of the Findings}

Demographic Composition of the Respondents

Out of the 250 copies of the questionnaire administered, 246 copies were found useable on return; representing 98.4\%. It comprises 128 copies for Mass Communication and 118 for Library and Information Science Departments respectively; with 129 male and 117 female among which are 122 Muslims and 124 Christians. Their age range was between 17 and 26. Majority of responses concerning respondents' parental occupations indicate predominant civil servant fathers and petty/private practicing mothers dominant. Parental educational attainments, showed that but for a few who had post-graduate qualifications, majority others had the school leaving and post-primary school certificates, indicating that the respondents' parental educational attainments fall mainly in the low and middle cadres; similar to their socio-economic status, against the backdrop of their occupations.

Table 1: Respondents' Exposure to Reading, Sources of Reading Materials and Reading Interests

\begin{tabular}{|l|l|l|}
\hline \multicolumn{1}{|c|}{ Reading Exposure, Materials and Interests } & Frequency & $\mathbf{\%}$ \\
\hline Exposure to Reading & & \\
Since childhood & 48 & 7.3 \\
Since Primary School & 94 & 17.1 \\
Since Secondary School & 92 & 38.2 \\
At the Polytechnic & $\mathbf{2 4 6}$ & 37.4 \\
Total & & $\mathbf{1 0 0}$ \\
Sources of Reading Inspiration & & \\
Father & 22 & 8.9 \\
Mother & 18 & 7.3 \\
Siblings & 12 & 4.9 \\
Peer group & 96 & 39.1 \\
Teachers & $\mathbf{2 4 6}$ & 39.8 \\
Total & & $\mathbf{1 0 0}$ \\
Types of Materials Mostly Read & & \\
Notebooks & 108 & 43.9 \\
Textbooks & 97 & 39.5 \\
Novels & 23 & 9.3 \\
Newspapers and Magazines & 18 & 7.3 \\
Total & $\mathbf{2 4 6}$ & $\mathbf{1 0 0}$ \\
Reasons for Engaging in Reading & & \\
To pass examinations & 26 & \\
To gain wide knowledge & 22 & 10.6 \\
To improve spoken/written English & & \\
To impress my parents & & \\
\hline
\end{tabular}


To impress my teachers

For pleasure and recreation

Total

From the table, it is instructive that majority of the respondents scarcely had contact with reading engagement prior to getting to the post-primary institution. This explains why majority, 38.2\% and another 37.4\% indicated "since secondary school" and "at the Polytechnic" respectively. Insignificant $7.3 \%$ indicated "since childhood", followed immediately by $17.1 \%$ for "primary school". It is clear that respondents got inspired towards reading engagement mostly from their peers (39.1\%) and teachers $(39.8 \%)$. The home environment as typified by both parents and siblings had considerably low responses. This also agrees with the responses provided in respect of reading facilities like books, tables and chairs that are available in respondents' homes while seeking a balance with such other reading distractions as video, television and sound systems. With the preponderance of the available electronic gadgets in respondents' homes compared to a rather low response rate on book availability presents a rather gloomy home environment for inculcating and developing good reading habits. Thus, when confronted with the question on what they read mostly, the response pattern agrees further with the earlier related ones.

Typical of the characteristics of a poor reading background, the data confirmed that majority of the respondents are course/subject-based readers as reading notebooks $(43.9 \%)$ and lecturers' textbooks (39.5\%) respectively featured prominently. Only an insignificant 9.3\% and $7.3 \%$ others indicated novels, newspapers and magazines reading. This does not present a favourable picture of positive reading habits orientation; since both notebook and textbook readings are essentially "forced reading". They are done largely for utilitarian purposes such as for achieving success in examinations and interviews. More revealing of these facts are the data provided for the follow-up question bordering on the reasons for which respondents engage in reading. There is also follow-up information to support the fact that reading among the respondents was primarily for utility (examinations) which was the dominant response given (45.5\%). Equally important is that respondents did not seem to appreciate the good links between the desire to widen/sharpen one's knowledge as well as adopt a more rewarding and pleasurable use of leisure on the one hand and reading on the other. This is what the global picture presented by the data actually depicts. After all, reading for examination purposes cannot be said to be either recreational or pleasurable in the general sense of the words, implying that do not find reading enjoyable. 
Table 2: Respondents' Perception of Reading, its relationship with Academic Performance and Hindrances to formulating Good Reading Habits

\begin{tabular}{|l|l|l|}
\hline Perception of Reading, Academic Performance and Reading & Frequency & $\mathbf{\%}$ \\
\hline Habits Problems & & \\
\hline Perception of Reading & 48 & 19.5 \\
Reading is enjoyable & 32 & 13.0 \\
Reading is interesting & 81 & 32.9 \\
Reading is rewarding & 85 & 34.6 \\
Reading is boring & $\mathbf{2 4 6}$ & $\mathbf{1 0 0}$ \\
Total & & \\
Encouragement Focus for Siblings & 62 & 25.2 \\
Game Playing (Video and computer) & 53 & 21.5 \\
Video/Television Viewing & 63 & 25.6 \\
Listening to Music & 44 & 17.9 \\
Meeting Friends & 24 & 9.9 \\
Reading & $\mathbf{2 4 6}$ & $\mathbf{1 0 0}$ \\
Total & & \\
Period of Library Use for Reading & 35 & 14.2 \\
Nurse/Primary School Days & 69 & 36.2 \\
Secondary School Days & 122 & 49.6 \\
In the Polytechnic & $\mathbf{2 4 6}$ & $\mathbf{1 0 0}$ \\
Total & & \\
Reading influences Academic Performance & 105 & 42.7 \\
Strongly Agreed & 69 & 28.0 \\
Agreed & 40 & 16.3 \\
Disagreed & 32 & 13.0 \\
Strongly Disagreed & $\mathbf{2 4 6}$ & $\mathbf{1 0 0}$ \\
Total & & \\
Hindrances to Good Reading Habits & 89 & 36.2 \\
Home Environment of Students & 29.7 \\
Social and Economic Status of Parents & 8.9 \\
Availability of Relevant Library Reading Materials & 22 \\
Ambition/Determination of the Students & $\mathbf{2 4 6}$ \\
Total & $\mathbf{1 0 0}$ \\
\hline The & & \\
\hline
\end{tabular}

The fact that reading was hardly considered as enjoyable in the responses given is an indication of respondents' wrong perception of a wide variety of good, interesting and rewarding consequences of reading. This also gave an insight into why many of them indicated that they would rather stop reading either after their examinations or their courses of study or both. This probably accounts for why only $9.8 \%$ indicated "Reading" as their 
encouragement focus for their siblings. The data are instructive of the fact that what good reading habits they do not have, they cannot give, which explains why their encouragement focus for their siblings varied from reading. Also significant is that other sources of attraction, aside from reading, such as video and computer games playing (25.2\%), video/television viewing (21.5\%), listening to music (25.6\%) and meeting friends $(17.9 \%)$ were presented. These, they considered as being more profitable than reading. Meanwhile, probing into their reading interests and habits revealed that majority of them do most of their reading in the classroom after lectures and in their residence. Only a few indicated the library as where they normally go for reading, with a few who claimed to have the conducive atmosphere of the library in their residence. However, when asked as to where they usually go in search of needed reading materials, the library was a very prominent response. This may mean that majority did have, however faintly, an idea of the library. This may not be unconnected with the fact that many of them lack good library-visiting background/orientation.

The awareness on the need to visit the Library for cultivating good habits of reading, especially at the foundational stages of Nursery/Primary and Secondary Schools was quite low among the respondents. Perhaps, whatever little use of the library that they now have is the fall-out of the surrounding circumstances which made it rather mandatory for them to visit the library. If such visits could be related to serious academic studies, the data indicated that only at the present educational stage are the respondents so seriously involved. Probably due to their poor library-visiting orientation, majority of those who indicated visiting the Library do so mainly to read personal notebooks and textbooks (44.3\%), which did not portray a proper understanding of the concept, library use. This is contrary to those whose visit to the library is for reading and consulting such library materials as Textbooks, $(27.6 \%)$, Journals (7.7\%) as well as Newspapers and Magazines (20.4\%). Further probing revealed that poor services provision by the Library was partly responsible for user frustration in the Polytechnic (44.3\%), Inaccessibility to Needed Materials $(35.3 \%)$ and Non-availability of Needed Materials $(20.4 \%)$. This is an indication of where necessary strengthening and adjustments would be required in order to reduce users' frustration in the Library.

On whether or not good reading interests and habits relate to academic performance, many of them strongly agreed as expected even though that their understanding could have been limited to utilitarian reading mostly. This position was further strengthened by the overwhelming indication by the majority that students who engage in reading perform better academically than their counterparts who do not. On some of the factors that could facilitate positive reading interests and habits, responses range from Home Environment $(21.1 \%)$, Social and Economic Status of Parents (25.6\%), Availability of Relevant Materials in the Library (28.9\%) to Determination of the Students (24.4\%). It is instructive to note that the factors outlined are not only widespread but also well-represented. They provide insight into things or areas to look out for in facilitating good reading interests and habits among the students. Similar to these factors are the hindrances to developing good reading interests and habits. The data showed that the home environment remains a core determinant of students' reading interests and habits (36.2), then socio-economic status of parents (29.7\%). This result provides evidence to support the belief that the home, around which the two issues revolve, is 
the foundation to the entirety of an individual's life; and especially for the formation of good reading interests and habits.

\section{Implications of the Findings}

From the results, good reading interests and habits could be closely linked with the respondents' home background and environment; especially their parental socio-economic status. This will assist in establishing the links between both-a useful guide as to where to focus in this regard. Also, the results revealed that what the respondents considered as reading was from the utility perspective, connoting the reading of personal notebooks/textbooks either at home or in the library. This disposition is a direct consequence of lack of the right attitude towards books, reading and library use; especially the much-desired experience early enough in life. A situation whereby majority had exposure to reading only on entering higher institutions is unsatisfactory. It is not surprising then that many students read, in the true sense of the word, only when examinations are fast approaching, after which they seldom continue-the utilitarian reading.

Another significant finding is the availability of alternative attractions (video/computer games, video television/cable satellite and music) perhaps made reading the more unpopular, and reduces the urge and attraction to reading as a matter of preference. This partly explains why many students failed to enjoy reading while others consider it boring. It thus follows that they did not see reading as an encouragement focus for their siblings. Although they agreed that reading interests and habits relate closely with academic performance generally, they found it difficult to relate the inculcation and development of reading interests and habits to library use; due perhaps to the fact that many lack early knowledge, understanding and appreciation of the essence of library use in their educational pursuits and indeed, their entire developmental process. Lastly, it is instructive that the home factor (socio-economic status of their parents) also featured prominently in the findings-confirming further the inextricable link between the home and inculcation of good reading interests and habits. This is because to find practicable solution to the problem at hand, the results pointed to the effect that those factors/hindrances should take the center-stage.

\section{Conclusions}

This study concludes that the desired good reading interests and habits as are required for attaining academic success are lacking among the respondents. That they could not relate library use to the inculcation and development of reading interests and habits is rather undesirable. Reading along tests and examinations paths alone does not bring along with it the benefit of widening one's knowledge base and horizon and should therefore be discouraged among them.

\section{Recommendations}

On the basis of the above, the following are recommended:

a. Lecturers in this Polytechnic should discourage students' over-dependence on restricted textbooks and notebooks by giving them library-based assignments, home works and tutorials. This should be with a view to encouraging them search widely 
for relevant information during which process they are bound to increase in knowledge.

b. The Polytechnic Library authorities should embark on an aggressively purposeful acquisition of relevant materials that are of core interest to both lecturers and students of the institution. This should be a regular and indeed continuous exercise aimed at salvaging the poor condition of library collections in the various disciplines of study in the Institution. By this, students would be better encouraged towards embarking on reading for reasons beyond utility.

c. The Polytechnic authorities also have a responsibility in ensuring that statutory allocations due to the library are released continually while also monitoring its judicious application to the core areas of resource deficiencies. That way, the lots of the Institution's Library stand to be improved tremendously within a very short period; whereby the students' reading needs would have been substantially attended to.

d. The parents have a huge responsibility in ensuring that their children/wards are regularly provided for within the constraints of their financial realities. Providing necessary home accessories for achieving conduciveness is a fundamental responsibility, which must be met. Creating enabling socio-economic conditions at home would assist tremendously in encouraging the inculcation and entrenchment of good reading interests and habits in the youths. This is the desired home background and orientation needed for a life-long interests and habits formation in reading. 


\section{References}

Anderson, R. \& Pearson, P. (1984). A Schema Theoretic View of Basic Processes in Reading Comprehension. In Handbook of Reading Research. P. David Pearson (ed). New York: Longman.

Baker,L. \& Brown, A. (1984). Metacognitive Skills and Reading. P.Pearson (Ed), Handbook of Reading Research. New York: Longman.

Brozo, W. (1990). "Hiding Out in Secondary Content Classrooms: Coping Strategies of Unsuccessful Readers". Journal of Reading. February 1990, 324-328.

Cabral, D. (2002). New Methods in Reading Comprehension Research. Hillsdale, New Jersey: Lawrence Erlbaum Associates.

Clary, L. (1991). Getting “Adolescents to Read”. Journal of Reading. February 1991, 340-345.

Deavers, R. (2000). "The Effect of Instruction on Early Non-word Reading Strategies". Journal of Research in Reading. October 2000, 23,267-286.

Flavell, J. (1979). "Metacognition and Cognitive Monitoring: A New Area of Cognitive- developmental Inquiry. American Psychologist, 34, 10, 1979, 109-118.

Flood, J. (ed) (1984). Understanding Reading Comprehension: Cognition, Language and the Structure of Prose. Newark, Delaware: International Reading Association.

Gallo, D. (2007). "Reading Interests and Habits of Connecticut Students in Grades Four through Twelve". The Reading Matrix. 2 (3). September.

Gardner, M. \& Smith, M. (1987). "Does Perspective Taking Ability Contribute to Reading Comprehension?" Journal of Reading. 30, 4, 333-336.

Garner, R. (1987). "Strategies for Reading and Studying Expository Text". Educational Psychologist. 22, 3-4, 299-312.

Greenall, D. \& Swan, M. (1986). Effective Reading Skills for Advanced Students. Cambridge: Cambridge University Press.

Greene, B. (2001). "Testing Reading Comprehension of Theoretical Discourse with Cloze”. Journal of Research in Reading. 24 (1), 82-98.

Grellet, F. (1987). Developing Reading Skills - A Practice Guide to Reading Comprehension Exercises. Cambridge: Cambridge University Press.

Guthrie, J. T., Bennett, L. and McGough, K. (2007). Concept-Oriented Reading Instruction: An Integrated Curriculum to Develop Motivations and Strategies for Reading. Retrieved on $29^{\text {th }}$ June, 2007.

Higginbotham, S. (2006). "Reading Interests of Middle School Students and Reading Preferences by Gender of Middle School Students in a Southeastern State”.

Hopper, J. (2001). Promoting Active Reading Comprehension Strategies. Englewoods Cliffs: Prentice Hall.

Lindquist-Sandmann, A. (1987). "A Metacognitive Strategy And High School Students: Working Together”. Journal of Reading, January 1987, 326-332.

Kletzien, S. \& Bednar, M. (1988). "A Framework for Reader Autonomy: An Integrated Perspective”. Journal of Reading. October 1988, 30-33.

Mcwhorter, K. (2001). College Reading and Study Skills (8 th ed.), London: Longman Publishers. 
Marzano,R. \& Paynter, D. (1994). New Approaches to Literacy- Helping Students

Develop Reading and Writing Skills, Washington: American Psychological Association.

Okekwe, P. (2006). Proposal Developing Readership and Nurturing New Writers. Retrieved on 23th June, 2007 at http://findarticle.journalonline

Orasanu, J. (1986). Reading Comprehension: from Research to Practice. Hillsdale (NJ): Lawrence Erlbaum Associates.

Panigrahi, C. and Panda, K. C. (2002). "Reading Interests and Information Sources Of School Going Children : A Case Study of Two English Medium Schools Of Rourkela, India”. Practicing College Reading Strategies. 22 (2).

Pauk, W. (2001). How to Study in College. Boston (MA): Houghton Mifflin Company.

Perin, D. (1988). "Schema Activation, Cooperation and Adult Literacy Instruction, Journal of Reading". October 1988, 54-62.

Ruzic, R. (2001). "Lessons for Everyone: How Students with Reading- Related Learning Disabilities Survive and Excel in College Courses with Heavy Reading Requirements". Paper presented at the Annual meeting of the American Educational Research Association, Seattle, Washington. Retrieved August29, 2001 from URL http://www.cast.org/udl/LessonsforEveryone1540.cfm

Sager, M. (1989). Exploiting the Reading-Writing Connection To Engage Students In Text, Journal of Reading. October 1989,40-43.

Shapiro, E. (1996). “Academic Skills Problems- Direct Assessment and Intervention”. New York: The Guilford Press

Lindquist-Sandmann, J. (1987). “Does Basic Skills Education Affect Adults' Literacy Proficiencies and Reading Practices, Reading Research Quarterly, 35, (2), 226-243.

Smith, F. (1982) Understanding Reading. New York: Holt, Rinehart and Winston.

Smith, M. C. (1992). "Differences in the Everyday Reading Practices of Gifted and Non-Gifted Adolescents: Report from a Pilot Study". Paper presented at the annual meeting of the Mid-Western Educational Research Association, Chicago, IL, October 14-17.

Stachelek, D. A. (2005). "A Comparative Study of the Reading Interests and Habits of Grade 12 Students in Selected Canadian and American Schools".

Takase, A. (2007). "Japanese High School Students' Motivation for Extensive L2 Reading”. Reading in a Foreign Language. Volume 19 Number 1, April.

Stoefen-Fisher, J. M. (1990). "Teacher Judgments of Student Reading Interests: How Accurate are They?" Journal of Special Education and Communication Disorders. Department of Special Education and Communication Disorders, University of Nebraska-Lincoln. 1990 Jul; 135 (3): Pp. 252-6.

Tierney, R. \& Readence, J. (2000). Reading Strategies and Practices: A Compendium. Boston (MA) : Allyn Bacon Publishers.

Wong,T. (2000). Strategies of Discourse Comprehension. London: Academic Press.

Yaworski, J. (1998). "Why do Students Succeed or Fail ? A Case Study Comparison". Journal of College Reading and Learning. 29, (1), 57-72. 